\title{
IGF1R wt Allele
}

National Cancer Institute

\section{Source}

National Cancer Institute. IGF1R wt Allele. NCI Thesaurus. Code C51548.

Human IGF1R wild-type allele is located in the vicinity of $15 q 26.3$ and is approximately 309

$\mathrm{kb}$ in length. This allele, which encodes insulin-like growth factor 1 receptor protein, is involved in the regulation of apoptosis and cellular proliferation. 